\title{
Method of obtaining an organic polycrystalline scintillator for detecting beta-radionuclide sources in natural waters
}

\author{
A.Yu.Andryushchenko ${ }^{1}, K_{\text {.N.Belikov }}{ }^{1}$, N.Z.Galunov $^{2,3}$, \\ E.V.Martynenko ${ }^{2}$, I.V.Lazarev ${ }^{2}$, Ya.I.Polupan ${ }^{4}$, O.A.Tarasenko ${ }^{2}$ \\ ${ }^{1}$ State Scientific Institution STC "Institute for Single Crystals", National \\ Academy of Sciences of Ukraine, 60 Nauky Ave., 61001 Kharkiv, Ukraine \\ ${ }^{2}$ Institute for Scintillation Materials, STC "Institute for Single Crystals", National \\ Academy of Science of Ukraine, 60 Nauki Ave., 61001 Kharkiv, Ukraine \\ ${ }^{3}$ V.Karazin Kharkiv National University, 4 Svobody Sq., \\ 61022, Kharkiv, Ukraine \\ ${ }^{4}$ Kharkiv College of Trade and Economics of Kyiv National University of \\ Trade and Economics, 202 Klochkovskaya St., 61000 Kharkiv, Ukraine
}

Received March 29, 2018

The method of producing an organic polycrystalline scintillator with two-stage sorbent filled holes for detecting beta-emitting source of ${ }^{90} \mathrm{Sr}$ in natural water is proposed. That confirms that synthetic hydroxylapatite is the optimal sorbent to solving the problem. For the polycrystalline scintillator of $p$-terphenyl doped by 1,4-diphenylbutadiene-1,3 which has the holes filled with hydroxylapatite as a sorbent, the efficiency of detecting beta particles of ${ }^{90} \mathrm{Sr}$ isotope sorbed from the water sample reaches $90 \%$.

Keywords: organic polycrystalline scintillator, sorbent, hydroxylapatite.

Предложен способ изготовления органического поликристаллического сцинтиллятора с двухступенчатыми отверстиями, заполненными сорбентом, для обнаружения бетаизлучающего источника ${ }^{90} \mathrm{Sr}$ в природных водах. Подтверждено, что оптимальным сорбентом для решения такой задачи является синтетический гидроксилапатит. Для поликристаллического сцинтиллятора $n$-терфенила, активированного 1,4-дифенилбутадиеном-1,3, имеющим отверстия, заполненные сорбентом гидроксилапатитом, әффективность регистрации бета-частиц изотопа ${ }^{90} \mathrm{Sr}$, сорбированного с водной пробы, достигает $90 \%$.

Розробка органічних полікристалічних сцинтиляторів для задач виявлення радіонуклідних джерел бета-частинок у природних водах. А.Ю.Андрющенко, К.М.Бєліков, М.З.Галунов, С.В.Мартиненко, І.В.Лазарєв, Я.І.Полупан, О.А.Тарасенко.

Запропоновано спосіб виготовлення органічного полікристалічного сцинтилятора 3 двоступінчатими отворами, які заповнюються сорбентом, для виявлення бета-випромінюючого джерела ${ }^{90} \mathrm{Sr}$ у природних водах. Підтверджено, що оптимальним сорбентом для вирішення такої задачі $€$ синтетичний гідроксилапатит. Для полікристалічного сцинтилятора $n$-терфенілу, активованого 1,4-дифенілбутадієном-1,3, що має отвори, заповнені сорбентом гідроксилапатитом, ефективність реєстрації бета-частинок ізотопу ${ }^{90} \mathrm{Sr}$, сорбованого з водної проби, досягає $90 \%$. 


\section{Introduction}

Previously, the porous organic polycrystalline sorption-scintillation material has been designed to detect alpha and beta radionuclide sources of radiation in natural waters [1-3]. Such the materials are the most promising systems for detecting extremely low concentrations of radionuclides in water. Such the approach combines the properties of the sorbent of radionuclides and the scintillator that detects the radiation from the radionuclide. A sorption of a radionuclide from the water sample takes place and the accumulation radionuclide results in the scintillation signal generation. This technique allows us to realize $4 \pi$ detection geometry for short-range radiations and provides a high accuracy of experimental results.

The use of organic materials in such sorption-scintillation detectors is due to a number of advantages that characterize these materials. First of all, this is a high efficiency of detecting short-range radiations caused by a low probability of a particle backscattering due to their small effective atomic number. In addition, organic scintillators are non-hygroscopic. This allows us to use these materials directly with water samples.

The values of the light yield and optical transparency directly determine the value of the light output that is one of the main characteristic of the sorption-scintillation material. In [1-3] we obtained the polycrystalline material by the cold pressure using relatively high pressures. This resulted in a cracking of the single crystalline grains; and as the result, the polycrystalline samples had a low optical transparency. This reduced the possibility of wider application of such materials. Another disadvantage of such the method [1-3] is the lack of a mechanical strength of the obtained samples. The destruction of polycrystals edges is stronger than their central part; and as the result, such the mechanical properties did not allowed us to fix firmly them during the filtration. Some water during the filtration did not pass through the pores containing the sorbent, but flowed through the edges of the scintillator.

In recent years, we have significantly improved the technology of obtaining organic polycrystals. This allows us to obtain polycrystals with higher transparency, light output, mechanical strength and lower cost [4-12]. These polycrystals we obtain by hot pressing of grains or plates, which improves the conditions for their sintering, at reduced values of pressure, which eliminates their cracking. In addition, in some cases we avoid the most expensive stage of a single crystal growth. This approach greatly expanded the possibilities of creating perspective sorption-scintillation materials with improved characteristics. In this way, we have proposed an organic polycrystalline detector for the determination of radionuclides in water solutions with improved mechanical and scintillation characteristics, and with a high efficiency of detection. The paper tests such the detectors for example of determination of ${ }^{90} \mathrm{Sr}$ radionuclide as the source of beta particles in the model solutions.

\section{Technological approaches}

\subsection{Sorbent choice}

Based on the experimental conditions of the problem being solved, we determined those main characteristics, which sorbents should correspond for the identification of strontium in water. Namely, it is selectivity for a particular chemical element (strontium in our case), a high exchange capacity, and a mechanical strength. Also, sorbents should be colorless, radiation-table, and do not have their own luminescence. The most consistent with this set of requirements are high-silica zeolite and synthetic hydroxylapatite (SHA) [13]. It is why, we have chosen these materials for ${ }^{90} \mathrm{Sr}$ sorption. Some characteristics of these sorbents are given in the Table 1.

The disadvantage of Na-mordenit is both the low selectivity of strontium sorption and the appearance of some coloration. All this leads to a decrease in the light yield of the scintillators containing this sorbent. SHA has a higher selective ability. It is colorless, shows no luminescence under an action of UV-radiation and is radiation-stable.

The amount of ${ }^{90} \mathrm{Sr}$ in solutions before and after sorption was measured using spectrometer with inductively coupled plasma ICPAES (Thermo Jarell Ash Company). It was shown that SHA selectively absorbs up to $99.9 \%$ of ${ }^{90} \mathrm{Sr}$ in the range of $\mathrm{pH}$ from 7 to 11 , and its capacity to strontium is $1.09 \mathrm{mmol} / \mathrm{g}$. An absence of absorption of potassium (i.e. including and ${ }^{40} \mathrm{~K}$ ) and cesium (i.e. including and ${ }^{137} \mathrm{Cs}$ ) significantly increases the sensitivity of ${ }^{90} \mathrm{Sr}$ determination in water.

\subsection{Preparation of polycrystals}

The production of polycrystalline scintillators occurred in two stages. Namely, it was: the hot pressure of a raw material ac- 
Table 1. Characteristics of sorbents

\begin{tabular}{||c|c|c|c|c||}
\hline Sorbent & Chemical composition & $\begin{array}{c}\text { Preparation } \\
\text { method }\end{array}$ & $\begin{array}{c}\text { Capacity by Sr, } \\
\mathrm{mmol} / \mathrm{g}\end{array}$ & $\begin{array}{c}\text { Soption degree } \\
\text { of Sr, \% }\end{array}$ \\
\hline $\begin{array}{c}\text { Na-mordenit } \\
\text { (three-dimensional } \\
\text { structures silica) }\end{array}$ & $\mathrm{Na}_{2} \mathrm{O} \cdot \mathrm{Al}_{2} \mathrm{O}_{3} \cdot 3 \mathrm{SiO}_{2} \cdot 2 \mathrm{H}_{2} \mathrm{O}$ & $\begin{array}{c}\text { Nature } \\
\text { alumosilicate }\end{array}$ & 0.94 & $78-85$ \\
\hline $\begin{array}{c}\text { Hydroxylapatite } \\
\text { (inorganic anionite) }\end{array}$ & $\mathrm{Ca}_{10}\left(\mathrm{PO}_{4}\right)_{6}(\mathrm{OH})_{2}$ & $\begin{array}{c}\text { Inorganic } \\
\text { anionite }\end{array}$ & 1.09 & 99.9 \\
\hline
\end{tabular}

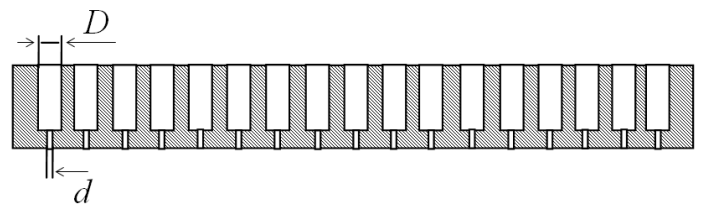

Fig. 1. Schematic representation of a polycrystalline sample of $p$-terphenyl with twostage holes.

companied by a subsequent drilling of coaxial holes those has two different diameters (see Fig. 1 and Fig. 2) direct introduction of a sorbent in these holes from the side of their larger diameter $D$ (Fig. 1).

We introduced the sorbent (Na-mordenite or SHA) in such the preliminary formed holes evenly distributed through the whole a sample when the minimal distance between such the hole and the edge a sample was not less than $1.0 \mathrm{~mm}$ (see Fig. 1 and Fig. 2). The formation of identical holes (with the same $D, d$ in depth) simplifies the procedure for introducing the sorbent, increases the efficiency of using the scintillator, and also prevents the leaching of the sorbent from the scintillator. The choice of a minimum distance between the holes and the edge of the scintillator of at least $1.0 \mathrm{~mm}$ already ensures the integrity of the edge of the scintillator, which leads to a higher mechanical stability of the scintillator, significantly reducing the probability of the water sample flowing out the edge of the scintillator during its saturation with ${ }^{90} \mathrm{Sr}$ by the water transmission method (for more details see Section 3).

We have experimentally determined the ranges of the technological parameters of the scintillator design (see Fig. 1). The diameter of the hole in it upper part $D$ may vary from 1.0 to $2.0 \mathrm{~mm}$, and in it lower part $d$ it may vary from 0.3 to $0.5 \mathrm{~mm}$. The depth of the hole may vary from 0.5 to $1.0 \mathrm{~mm}$. The ratio of the volume part of the holes to the entire volume of the scintillator should be from 12 to $50 \%$. If this value is less than $12 \%$, then the detection efficiency of the radionuclide emission is

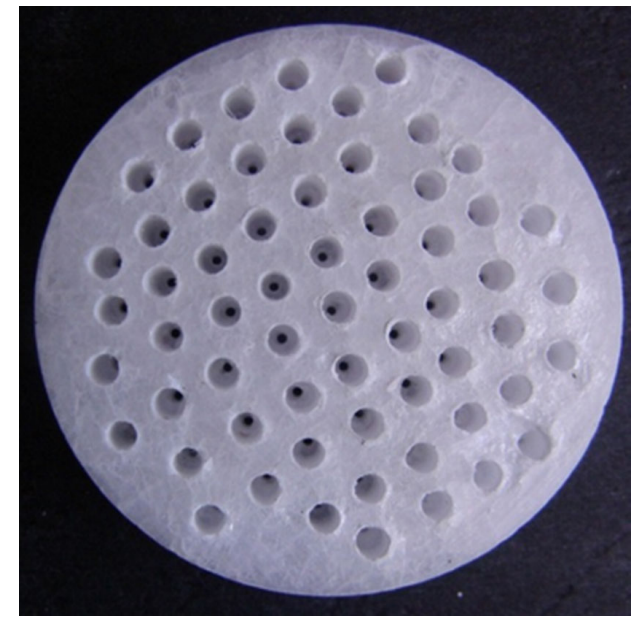

Fig. 2. Photography of a polycrystalline sample of $p$-terphenyl doped by 1,4-diphenylbutadiene-1,3 with two-stage holes.

greatly reduced, and if this value is more than $50 \%$, then the mechanical properties of the polycrystal deteriorate. Reducing the size of diameters $D$ and $d$ (see Fig. 1) to values less than 1.0 and $0.3 \mathrm{~mm}$, respectively, leads to difficulties with the introduction of the necessary amount of sorbent. The increase in diameters to values exceeding 2.0 and $0.5 \mathrm{~mm}$, respectively, leads to a decrease in the total contact area of the sorbent material with the scintillator. When the depth of the lower part of the hole (Fig. 1) is less than $0.5 \mathrm{~mm}$, the polycrystalline sample may begin to break down, which will result in the washing out of the sorbent from it. An increase in the depth of the lower part of the hole (Fig. 1) of more than $1.0 \mathrm{~mm}$ is not advisable, since in this case the amount of sorbent in the whole scintillator is unreasonably reduced.

For our investigations we have made the polycrystalline samples of $p$-terphenyl doped by 1,4-diphenyl-1,3-butadiene (0.3 wt.\%) [14] with the diameter of $32 \mathrm{~mm}$ and the thickness of $4.5 \mathrm{~mm}$. To obtain polycrystals we have used $p$-terphenyl plates previously obtained from a solution. These plates charged into a metal mould with the diameter of $32 \mathrm{~mm}$. 
We prepared the polycrystals according to the following procedure. Plates of $p$-terphenyl were grown from solution. Then these plates were poured into a metal mould with a diameter of $32 \mathrm{~mm}$. The mould was placed in a heater and under a press. It was kept during $3 \mathrm{~h}$ under a pressure of $50 \mathrm{MPa}$ and a temperature of $160^{\circ} \mathrm{C}$. Then the temperature decreased at a rate of $2^{\circ} \mathrm{C} / \mathrm{h}$ to the room temperature, and the pressure was reduced at a rate of $1 \mathrm{MPa} / \mathrm{h}$ to $0 \mathrm{MPa}$. After that, the holes have been drilled in polycrystalline samples (see Fig. 1). We prepared two types of polycrystalline samples. For the first type we done 63 holes with $D=$ $1.5 \mathrm{~mm}$, and the second type of the samples has 140 holes with $D=1.3 \mathrm{~mm}$. For all the polycrystals, $d=0.4 \mathrm{~mm}$, the depth of the bottom part of the holes was equal to $0.5 \mathrm{~mm}$. After this, the material which remained in the holes we removed by a stream of air and filled with sorbent. Before use, the sorbent was ground in a porcelain mortar and sieved through the calibration sieves. To ensure maximum filling of the holes, the sorbent was moistened with distilled water. To fill the holes we used a water jet pump.

2.3. Saturation of sorbent-containing organic polycrystals with ${ }^{90} \mathrm{Sr}$

The methods of the dynamic and static sorption have been used for a saturation of a sorbent with a radionuclide. Dynamic sorption presupposes a free or water-jet pump flow of a water sample through a scintillator with holes (hereafter porous scintillator). A sorption was carried out using $100 \mathrm{ml}{ }^{90} \mathrm{Y}+{ }^{90} \mathrm{Sr}$ model solution containing $25 \mathrm{Bk}$ of ${ }^{90} \mathrm{Sr}$. The time of percolation of the solution through a polycrystal was equal to $1 \mathrm{~h}$. The static sorption was an immersion of a porous scintillator into $100 \mathrm{ml}{ }^{90} \mathrm{Y}+{ }^{90} \mathrm{Sr}$ model solution containing $25 \mathrm{Bk}$ of ${ }^{90} \mathrm{Sr}$ and its stirring by a magnetic stirrer within $1 \mathrm{~h}$. In both cases after the sorption procedure all scintillators were dried for $5 \mathrm{~min}$ and after that their scintillation amplitude spectra were immediately measured.

\section{Experimental}

\subsection{Relative light output}

The relative light output of polycrystalline scintillators we determined by the standard method of scintillation amplitude spectra measurements. We run the measurements using the 9208A photomultiplier tube (Electron Tubes Ltd). To obtain the ampli- tude distribution of pulses from a scintillator we used the multichannel amplitude analyzer AI-1024-95.

The relative light output is equal to

$$
L=\left(J / J_{r e f}\right) \cdot 100 \%,
$$

where $J$ is the amplitude that corresponds to the centre of peak gravity in the spectrum of the scintillator under investigation, $J_{r e f}$ is the value of the amplitude that corresponds to the centre of a peak gravity in the spectrum of the reference scintillator. The error of determining the $L$-value output is equal to $5 \%$ [15]. As the source of an ionizing radiation we used ${ }^{239} \mathrm{Pu}$ (alpha particles with the energy $E_{\alpha}=5.15 \mathrm{MeV}$ ).

3.2. Determination of ${ }^{90} \mathrm{Sr}$ activity introduced into polycrystalline scintillators

In measurements of radiation emitted by sources of low-activity ionizing radiations, it is problematic to separate low-intensity and weak useful signals from the signals of background radiation, including the dark noise of a photomultiplier. Therefore, in our experiments we used 9208A photomultiplier tube (Electron Tubes Ltd) with the value of a dark current equal to $6 \cdot 8 \cdot 10^{-11} \mathrm{~A}$ for anode sensitivity of $50 \mathrm{~A} / \mathrm{lm}$ [16]. To take into account the effect of dark current pulses and background pulses we have measured the polycrystalline samples, which does not contain ${ }^{90} \mathrm{Sr}$ isotope. All samples were placed on the surface of the input window of the photomultiplier tube. The analysis of amplitude spectra of the samples we run using the multichannel amplitude analyzer AI-1024-95 connected to the computer.

The isotope of ${ }^{90} \mathrm{Sr}$ decays into the isotope of ${ }^{90} \mathrm{Y}$ [17]. A reduction of the time of preparation of samples before the measurements of their activity up to $1 \mathrm{~h}$ and carrying out these measurements immediately after the end of sorption process leads to transformation only $2.7 \cdot 10^{-4} \mathrm{rel} . \%$ of ${ }^{90} \mathrm{Sr}$ into ${ }^{90} \mathrm{Y}$. It allows us for such the conditions to exclude the influence of daughter ${ }^{90} \mathrm{Y}$ on the results of the analysis [2].

The area under the curve of an amplitude distribution spectrum gives the total number of detected pulses from the investigated sample. Thus, the detected activity of samples after their saturation we calculated from amplitude scintillation spectra according to the formula:

$$
A=\frac{N-N_{b g}}{t},
$$


where $N$ is the total number of the pulses under the amplitude spectrum curve for the sample saturated with ${ }^{90} \mathrm{Sr}, N_{b g}$ is the total number of the pulses under the amplitude spectrum curve for the sample, which does not contain ${ }^{90} \mathrm{Sr}$ (background events), $t$ is the measurement time (the time of each measurement was equal to 40 minutes).

\section{Results and discussion}

We investigated 10 polycrystalline samples obtained by the hot pressure from the plates of $p$-terphenyl doped by 1,4-diphenyl-1,3-butadiene. For all these samples, we obtained the value of the relative light output for irradiation by alpha particles of ${ }^{239} \mathrm{Pu}$. We used the single crystal of $p$-terphenyl with the diameter of $20 \mathrm{~mm}$ and the height of $5 \mathrm{~mm}$ as the reference scintillator. The scintillation amplitude spectra measurements (see Section 3.1) allow obtaining the relative light output $L$ (1).

Fig. 3 shows the $L$-values for polycrystals averaged over three independent measurements those run for one the same sample. The samples numbered as 4,9 and 10 fall out appreciably of the general trend. The fact is that the technology that we have developed allows pressing simultaneously several samples in the middle of a metal mould. Thus, samples 1 and 2 were simultaneously pressed in the first pressing, samples 3,4 and 5 were pressed in the second one, samples 6,7 and 8 were pressed in the third one, and samples 9 and 10 were separately pressed in the fourth and fifth pressings, respectively. If the pressure technology of only one sample (for example, samples 9 and 10) is sufficiently developed, then the more economic technology when several samples are pressed simultaneously needs further improvement. Perhaps this is due to the non-optimal conditions of heat transfer during pressing that requires additional study. For example, for samples 6,7 and 8 we see higher $L$-values than for samples 3,4 and 5 .

For further studies from the whole set of the samples we selected those for which a spread of the $L$-value did not exceed $\pm 5 \%$. These are polycrystals numbered $1,2,3,5$, 6, 7 and 8 (see Fig. 3). This allows us to avoid the significant effect of a spread of the $L$-value on the measurements of the detection efficiency of ${ }^{90} \mathrm{Sr}$.

Firstly, we chose the more effective method of ${ }^{90} \mathrm{Sr}$ introducing: i) the dynamic

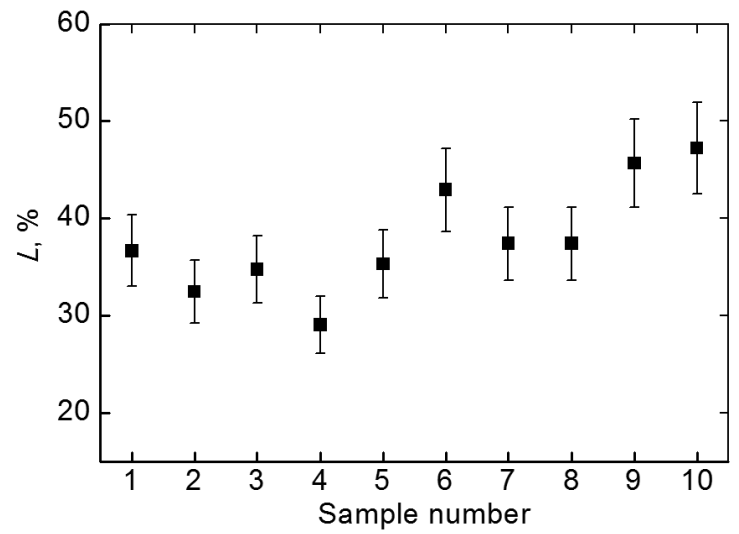

Fig. 3. Values of the relative light yield $L$ (1) for the polycrystalline samples of $p$-terphenyl doped by 1,4-diphenylbutadiene-1,3 obtained by the hot pressure technique.

method (a percolation of a solution through a material) or ii) the static one (an immersion of a material into a solution). Two polycrystals we used for this purpose. In both polycrystals we made the holes with $D$ $=1.5 \mathrm{~mm}$ that were filled with SHA sorbent. One of the polycrystals saturated with ${ }^{90} \mathrm{Sr}$ by the method of percolation of ${ }^{90} \mathrm{Y}+{ }^{90} \mathrm{Sr}$ radioactive water solution, and the other sample saturated by the immersion method. In $100 \mathrm{ml}$ of an aqueous sample that we used there was an amount of ${ }^{90} \mathrm{Sr}$ which had an activity of $25 \mathrm{~Bq}$. We run the measurements of amplitude scintillation spectra of these polycrystals immediately after their saturation with ${ }^{90} \mathrm{Sr}$. To determine the background events we used the polycrystal with SHA non-saturated with ${ }^{90} \mathrm{Sr}$. After that we calculated the detected activity $A$ of the samples by Eq. (2) using the measurements of the amplitude scintillation spectra. Table 2 shows the results of these calculations.

At the next stage of our research, we chose the more efficient type of a sorbent and tested the effect of the $D$-value and the number of holes on the value of the detected activity. Four polycrystals we used for this purpose. In two polycrystals the holes with $D=1.5 \mathrm{~mm}$, and in the other two the holes with $D=1.3 \mathrm{~mm}$ were made. In two polycrystals (with $D=1.5 \mathrm{~mm}$ and $D$ $=1.3 \mathrm{~mm}$ ) the holes were filled with SGA sorbent, and in the other two polycrystals the holes were filled with $\mathrm{Na}$-mordenite sorbent. Then the polycrystals were saturated with ${ }^{90} \mathrm{Sr}$ by the percolation method. The concentration of ${ }^{90} \mathrm{Sr}$ in the solutions was chosen that $100 \mathrm{ml}$ water sample had $25 \mathrm{~Bq}$ 
Table 2. Values of the detected activity $A$ measured by the polycrystalline samples of $p$-terphenyl doped by 1,4-diphenylbutadiene-1,3

\begin{tabular}{|c|c|c|c|c||}
\hline $\begin{array}{c}\text { Sample } \\
\text { number }\end{array}$ & $D, \mathrm{~mm}$ & Sorbent & Method of saturation by ${ }^{90} \mathrm{Sr}$ & $A$ \\
\hline 1 & 1.5 & SHA & Percolation & 18.8 \\
2 & 1.5 & Na-mordenite & Percolation & 3.8 \\
3 & 1.3 & Na-mordenite & Percolation & 9.8 \\
6 & 1.3 & SHA & Percolation & 21.3 \\
7 & 1.5 & SHA & Percolation & 16.6 \\
8 & 1.5 & SHA & Immersion & 0.9 \\
\hline
\end{tabular}

activity of ${ }^{90} \mathrm{Sr}$. To determine background events we used the polycrystals containing Na-mordenite or SGA, but without ${ }^{90} \mathrm{Sr}$. The measurements of amplitude scintillation spectra of polycrystals we run immediately after the saturation procedure. As an example, Fig. 4 shows amplitude scintillation spectra for the polycrystals containing SHA as a sorbent. Using these spectra we calculated the detected activity $\mathrm{A}$ of the samples by Eq. (2). Table 2 also presents the results of these calculations.

The analysis of the Table 2 data shows that the immersion method is extremely ineffective for the preliminary sorption of $90 \mathrm{Sr}$ from a water sample. A use of $\mathrm{Na}$-mordenite as a sorbent also does not provide satisfactory results. A reduction of the diameter $D$ of the upper part of the holes from 1.5 to $1.3 \mathrm{~mm}$ together with an increase in the number of the holes (see Section 2.2) results in an increase in the value of the detected activity $A$. The most effective sorption and detection of ${ }^{90} \mathrm{Sr}$ is obtained for the following combination of technological parameters: i) $D=1.3 \mathrm{~mm}$; ii) SHA sorbent; iii) the percolation method for the preliminary sorption of ${ }^{90} \mathrm{Sr}$ (sample 6 in Table 2).

To verify a reliability of the results obtained for sample 6, we have produced two additional samples (numbered in Table 3 as 11 and 12) with the same design parameters as for sample 6 . Table 3 presents the $A$-values of samples 6,11 and 12 .

Not all sorbent can remain in the sample during its saturation with ${ }^{90} \mathrm{Sr}$ from a water sample, and some of it can leak out from polycrystalline samples. Therefore, for a correct comparison of the results obtained for samples 6,11 , and 12 we measured the relative amount $k$ of SHA that remained in the samples of polycrystals after their saturation. We calculated the $k$-value as the difference between the total mass of a scintillator and a sorbent before and after sorption.

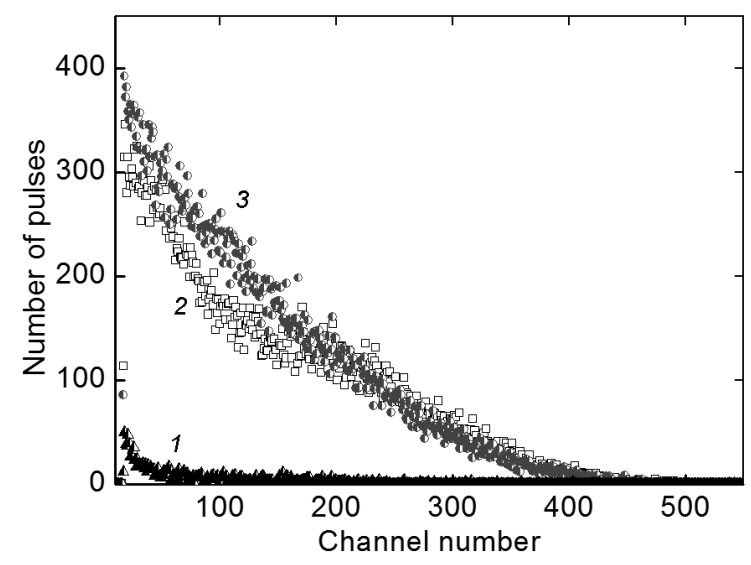

Fig. 4. Scintillation amplitudes spectra for the $p$-terphenyl polycrystals doped by 1,4 diphenyl-1,3-butadiene containing SHA sorbent after theirs saturation by ${ }^{90} \mathrm{Sr}: 1$ is the polycrystal without ${ }^{90} \mathrm{Sr}$ (background pulses); 2 is the polycrystal with holes $D=1.5 \mathrm{~mm} ; 3$ is the polycrystal with holes $D=1.3 \mathrm{~mm}$.

In addition, for these samples we carried out the measurements of the sorption degree $s$ of ${ }^{90} \mathrm{Sr}$ with SHA sorbent (see Table 3 ).

This allowed us to calculate the detection efficiency $E$ (see Table 3 ) of ${ }^{90} \mathrm{Sr}$ that was sorbed from the water sample in accordance with the formula

$$
E=\frac{A}{25 \cdot s \cdot k} \cdot 100 \%,
$$

Table 3. Efficiency of the detection of ${ }^{90} \mathrm{Sr}$ beta-particles by the $p$-terphenyl polycrystals doped by 1,4-diphenyl-1,3-butadiene (with $D=1.3 \mathrm{~mm}$ and SHA sorbent)

\begin{tabular}{|c|c|c|c|c||}
\hline $\begin{array}{c}\text { Sample } \\
\text { number }\end{array}$ & $\begin{array}{c}A, \\
\text { pulses/sec }\end{array}$ & $s, \%$ & $\begin{array}{c}k, \\
\text { rel.units }\end{array}$ & $E, \%$ \\
\hline 6 & 21.3 & 99.3 & 0.95 & 90.3 \\
11 & 19.0 & 99.0 & 0.92 & 83.4 \\
12 & 20.3 & 99.1 & 0.94 & 87.2 \\
\hline
\end{tabular}


where the $s$-values are also calculated in relative units. One can see that for the studied samples of polycrystalline scintillators the $E$-value may reach about $90 \%$.

\section{Conclusions}

The method of producing organic polycrystalline scintillator with two-stage holes filled with sorbent for detecting beta-emitting source of ${ }^{90} \mathrm{Sr}$ in natural waters is proposed.

The ranges of the technological parameters of the design of the organic polycrystalline scintillator with two-stage holes were determined, namely: the diameters of the upper and the bottom parts of the hole, the depth of the lower part of the hole, the minimal distance of the holes from the edge of the polycrystal, the ratio of the volume fraction of the holes to the total volume of the polycrystal.

For the polycrystalline scintillator of $p$-terphenyl doped by 1,4-diphenylbutadiene1,3 having holes filled with hydroxylapatite as a sorbent, the efficiency of detection of beta particles of ${ }^{90} \mathrm{Sr}$ sorbed from the water sample is in the range of $83-90 \%$.

\section{References}

1. Patent N57950A.

2. A.Yu.Andryushchenko, A.B.Blank, S.V.Budakovsky et al., Nucl. Instrum. Meth. Phys. Res., A511, 425 (2003).
3. A.Yu.Andryushchenko, A.B.Blank, S.V.Budakovsky et al., Anal.Chim.Acta, 480, 151 (2003).

4. Patent 55633.

5. N.Z.Galunov, I.G.Homyakova, E.V.Martynenko et al., Probl. Atom. Sci. Techn., 4, 214 (2006).

6. T.E.Gorbacheva, N.Z.Galunov, V.D.Panikarskaya, I.V.Lazarev, Functional Materials, 20, 149 (2013).

7. T.E.Gorbacheva, N.Z.Galunov, I.V.Lazarev et al., J. Appl. Spectr., 81, 164 (2014).

8. N.Z.Galunov, T.E.Gorbacheva, N.L.Karavaeva et al., Materialovedenie, 4, 51 (2014).

9. N.Z.Galunov, I.V.Lazarev, A.D.Samokhin. Ukraine Patent 106026.

10. I.V.Lazarev, Materialovedenie, 4, 47 (2015).

11. N.Z.Galunov, V.P.Seminozhenko, Radioluminescence of Organic Condensed Media, Naukova Dumka, Kyiv (2015).

12. Yu.V.Milman, N.Z.Galunov, S.I.Chugunova et al., Nanosistemy, Nanomaterialy, Nanotehnologiy, 14, 461 (2016).

13. V.S.Komarov, Adsorbents and their Properties, Nauka i Technika, Minsk (1977) [in Russian].

14. N.Z.Galunov, I.V.Lazarev, E.V.Martynenko et al., Mol. Cryst.Liq. Cryst., 615, 176 (2015).

15. E.Sysoeva, V.Tarasov, O. Zelenskaya, Nucl.Instrum. Meth. +., A486, 67 (2002).

16. Photomultipliers, Ruislip, UK: Electron Tubes Enterprises Limited (2007).

17. Radionuclide Transformations. Energy and Intensity of Emission, ICRP Publication 30, Pergamon Press, New York (1987). 